\title{
Kinetic Study of Redox Probes on Glassy Carbon Electrode Functionalized by 4-nitrobenzene Diazonium
}

\author{
William Richard, David Evrard*, Pierre Gros \\ Laboratoire de Génie Chimique, Université de Toulouse, CNRS, INPT, UPS, Toulouse, France \\ *E-mail: evrard@chimie.ups-tlse.fr
}

doi: $10.20964 / 2019.01 .22$

Received: 23 July 2018 / Accepted: 22 August 2018 / Published: 30 November 2018

The electrochemical behavior of organic films grafted onto glassy carbon (GC) and bearing $\mathrm{NO}_{2}, \mathrm{NHOH}$ or $\mathrm{NH}_{2}$ groups was studied by using three different redox probes, namely ferricyanide $\mathrm{Fe}(\mathrm{CN})_{6}{ }^{3-}$, hexaammineruthenium(III) $\mathrm{Ru}\left(\mathrm{NH}_{3}\right)_{6}{ }^{3+}$ and ferrocenemethanol FcMeOH. Films were prepared by grafting 4-nitrobenzene diazonium onto the GC surface by constant potential electrolysis for durations varying from 1 to $300 \mathrm{~s}$. $\mathrm{NO}_{2}$ groups were converted into $\mathrm{NHOH}$ and $\mathrm{NH}_{2}$ by performing further electrolyses at the corresponding potentials. The redox probes were chosen because of their different global charge and electron transfer process. For all the as-obtained films, the Koutecky-Levich treatment was applied and the cathodic $(\beta)$ and anodic $(\alpha)$ transfer coefficients were extracted. All these data were discussed and compared in order to better understand the structure and the electrochemical properties of the organic films.

Keywords: 4-nitrobenzene diazonium; electrode functionalization; stratified film; Koutecky-Levich analysis; electrochemical kinetics; redox probes

\section{FULL TEXT}

(C) 2019 The Authors. Published by ESG (www.electrochemsci.org). This article is an open access article distributed under the terms and conditions of the Creative Commons Attribution license (http://creativecommons.org/licenses/by/4.0/). 